sciendo Порівняльна професійна педагогіка 9(3)/2019 Comparative Professional Pedagogy 9(3)/2019

DOI: $10.2478 /$ rpp-2019-0028

$\mathrm{PhD}$ in Pedagogy, Associate Professor, OLENA TERENKO

A. S. Makarenko Sumy State Pedagogical University Address: 87 Romenska St., Sumy, 40000, Ukraine

E-mail: eterenko@ukr.net

\title{
TECHNOLOGIES OF ADULT EDUCATION: NORTHERN-AMERICAN EXPERIENCE
}

\section{ABSTRACT}

Factors that influence motivation are split into external and internal. Key peculiarities of adult who learns are found out. A person who studies can trace connection between educational needs and solution of everyday life problems. Basic terms of learning efficiency are: self-orientation and independence. The main principles of adult education are systematized. They are the following: necessity to know, consciousness, willingness to learn, focus on learning, intrinsic motivation, self-orientation, relying on experience, situational, practice-orientation, motivation. The concept "educational technology" is analysed. Educational technology is systematic targeted approach to learning that combines specific teaching methods, educational technology, and takes into account psychological part of the learning process - relationship between learners and those who teach; systemic ways of activities of those who teach and those who study for the effective achievement of learning goals. Principles of educational technology usage are outlined. They are: individualization, creativity, self-motivation, cooperation, activity. The gist of interactive technology is found out. Interactive learning technology is based on the interaction between participiants of training; organization of joint activities based on dialogic teaching methods; a way of organizing learning of adults considering the needs, interests, personal and professional experience. Basic forms and methods of adult's interactive teaching in the USA are: conversation, discussion, collective solving of creative situations, the method of "round table", project method, playing techniques, mentorship, coaching - training in small groups, storytelling, method of narrative.

Keywords: technology, adult education, coaching, storytelling, narrative method, budding, semulation, debate.

\section{АНОТАЦІЯ}

Виділені зовнішні та внутрішні фактори, щяо впливають на мотивацію. Розглянуто ключові особливості дорослої людини, яка навчається. Дорослий учень може прослідкувати зв'язок між освітніми потребами та шляхами вирішення побутових потреб. Ключовими засадами ефективності навчального прочесу $\epsilon$ саморієнтаиія та незалежність. Систематизовано основні принципи освіти дорослих, а саме потреба навчатися, свідомого сприйнятття навчального процесу, врахування досвіду учасників навчального процесу, бажання навчатися, концентрація на навчальній діяльності, самоорієнтації, ситуативності, практико- орієнтованості, вмотивованості. Розглянуто сутність концепту «навчальна технологія». Технологія навчання - це систематичний цілеспрямований підхід до навчальної діяльності, який поєднує навчальні методи, освітні технології і бере до уваги психологічну частину освітнього процесу - стосунки між вчителем та учнями; організація спільної діяльності на засадах діалогічних методів; систематичні способи діяльності викладача та 
студентів для ефективного досягнення навчальних иүілей. Окреслено принциипи використання освітніх технологій, а саме індивідуалізації, креативності, самомотивації, взаємодії, активності. Проаналізовано сутність концепту «інтерактивна технологія». Інтерактивна технологія передбачає взаємодію учасників навчання, організацію спільної навчальної діяльності з використанням діалогічних методів; спосіб організаціі навчальної діяльності дорослих з урахуванням їх потреб, інтересів, особистого $i$ професійного досвіду. Основними формами і методами навчання дорослих у США бесіда, дискусія, колективне вирішення творчих ситуацій, круглий стіл, метод проектів, гра, наставництво, навчання в малих групах, розповідь.

Ключові слова: технологія, освіта дорослих, бадінг, симуляція, дискусія.

\section{INTRODUCTION}

In the conditions of globalization and integration, development of knowledge society, there is a transition to conception of life-long education as important factor of society development, main factor of specialists' efficiency and power of state, means of adults' adaptation to changes in society. Meanwhile life-long education determines development of informal adult education as sociocultural phenomenon, as its equal component that is stated in documents of UNESCO, CEDEFOR, OECD and causes necessity of searching optimal ways of adult education development. Northern American countries - are countries that have recognized world positive experience of informal adult education development, its transformation into powerful factor of nation's intellect increase.

\section{THE AIM OF THE STUDY}

\section{American countries.}

The aim of the study is to analyse techonologies of adult education in Northern

\section{THEORETICAL FRAMEWORK AND RESEARCH METHODS}

The problem of adult education was researched by such Ukrainian scientists as N. Bidyuk (2009), O. Ogienko (2014). Different aspects of adult education in the USA and Canada were analyzed by foreign scientists: basic adult education (D. Amstutz, 2011; B. Lasater, 2014), principles of adults training (M. Knowles, 1984), adult literacy (Askov, 2016; Barton, 2015; Fingeret, 2017). To fulfill the aim of our research we will apply the following methods: analysis, synthesis, induction, deduction, analogy, comparative historical method, genetic method, problem-chronological method.

\section{RESULTS}

American scientists conducted intensive research on features of adult learning, especially, effective forms, methods and technologies.

P. Barton states, "optimization of adult education depends on understanding of characteristics of both adult learners and their consideration of organizing learning process" and J. Merrifield pays attention to the fact that "theory of adult education begins and is based on fundamental differences in adult learning in comparison to teaching a child" (Barton, 2015; Merrifield, 2018).

In this context, it is important to pay attention to the fact that American scientist M. Knowles (1984), who is called the "father of adult education in the USA", for the first time analyzed practice of informal education of adults in the United States of America and created the theory of adult education.

M. Knowles singles out features and principles of adult learning, which become the basis for creating models of andragogical training. Research shows that modern science and practice of adult education is based on scientific works of M. Knowles, in which key 
features of adult learning are outlined: necessity to know - an adult should understand the need of knowledge, opportunity of its usage in practical activities; self-responsibility adult is able to take responsibility for his own learning; availability of social and professional experience, which becomes a source of knowledge, the basis of the learning process; willingness to learn - adults are willing to acquire knowledge that will enable them to solve specific problems in life; focus on learning - learning is focused on adult life. Adults learn , for they understand that learning will help in solving real-life situations; motivation is influenced by both external factors (reward, punishment, career, higher wages, etc.), and internal (quality of life, job satisfaction, self-esteem, etc.). However, the dominant factors are internal. (Levine, 2016; Quigley, 2017).

Thus, the main criterion that determines features of the adult who learns is connection between educational needs and solution of practical problems in life. This activity promotes independence and adult learning. According to K. Levine (2016), the first feature of adult student - is necessity to know: how learning will occur, which will be the content of education, why it is important to him and how he will apply learning outcomes in practice.

Adapting the definition of adulthood for organization of the process of adult education one can distinguish terms of efficiency: self-orientation and independence.

Features of the adult learner become the basis of the organization and implementation process of adult learning in different types of formal education in determining the forms and methods of adult learning, principles of andragogical training.

The most common and reasonable is a system of principles of adult learning that proposed by M. Knowles (1984) and that meets the criterion traits of adult student: necessity to know, consciousness, experience, willingness to learn, focus on learning, intrinsic motivation, self-orientation, relying on experience, situational, practice-orientation, motivation).

We found out that modern researchers supplemented and refined andragogical principles of learning that were offered by M. Knowles. It includes the following principle: prioritizing of self-study and reliance on subjective experience (social and professional) of the student, individualization of learning. This principle is fulfilled in terms of informal adult distance learning, allowing an adult to organize his own learning, take away literature, select the content, pace, time, training, etc. In the informal learning the principle of reliance on experience plays a leading role as an adult looking to expand his existing experience, based on the one that came before it or adjusting it. The principle of individualization of learning, which ensures that the learning process takes into account needs of adults.

Objective necessity of improving quality of informal adult education has led to the use of innovative technologies.

The concept "educational technology" is understood by American scientists as "systematic targeted approach to learning that combines specific teaching methods, educational technology, and takes into account psychological part of the learning process - relationship between learners and those who teach"; as "systemic ways of activities of those who teach and those who study for the effective achievement of learning goals" (Barton, 2015).

B. Lasater (2014) singles out principles of usage of educational technology in teaching adults: individualization, creativity, self-motivation, cooperation, activity.

The most widely spread technology of adult education in the USA informal education is interactive technology. According to J. Comings (2016), interactive technology features adults to ensure effectiveness of informal adult learning.

Interactive learning technology is seen by G. Demetrion (2005) as being based on the interaction between participiants of training; organization of joint activities based on 
dialogic teaching methods; as a way of organizing learning of adults considering the needs, interests, personal and professional experience.

Effective implementation of interactive learning technologies in the practice of informal adult education involves determining principles of the USA usage of interactive technology. The principles are the following: dialogic interaction, game activity, cooperation and collaboration, training activity (Askov, 2016).

A study conducted by the American Association of Extended and Adult Education showed that the main advantage of usage of interactive teaching technologies is the possibility of organizing creative interaction of education, that promotes "discovery" of new knowledge, acquiring of new skills (Merrifield, 2018). Application of interactive technologies in informal adult education presupposes that teacher becomes facilitator, consultant who helps, guides, advises adults in finding solution of problems. This fact indicates that the usage of interactive technologies in informal education allows adults to move away from the usual logic of the learning process, which involves moving from theory to practice and begin forming a new experience - which can be gradually theoretically comprehended.

Basic forms and methods of adults interactive teaching in the USA are: conversation, discussion, collective solving of creative situations, the method of "round table", training, project method, playing techniques and mentorship, coaching - training in small groups, storytelling, method of narrative and others.

An integral part of the functioning of informal education of adults in the USA are coaching, which is defined as: the type of training in the form of communication aimed at disclosing the opportunities and potential of adult who is trained; art of creation of environment (educational, psychological) to enhance the effectiveness of training and providing conditions for the development of students (Demetrion, 2005). The essence of coaching is responsible nature of informal adult education, allowing through the analysis of the educational needs of adults specify its goals, objectives and outline an action plan to help them achieve results by creating appropriate conditions, updating existing social and professional experience.

Storytelling in the practice of informal education has been used recently. It has been developed and first used by D. Armstrong - the head of an international company to create corporate values and culture. The method presuposes broadcasting of stories that most fully reveal and illustrate certain values, information, events, etc. With the help of history and stories (myths, stories, important events, etc.) storytelling helps to remember the importance of increasing training and has better impact on behavior. For example, the University of the Third Age in New York is famous for "golden fund" stories relating to both the institution and the history of many personalities, not only of famous people, but also life stories of ordinary people.

Finding a solution to a particular life situation is based on analysis of certain stories, for stories (positive or negative) promote critical thinking, teach to analyze, justify one's own point of view and so on.

One of the essential characteristics of the learning process is adult's appeal to his personal and professional experience. Therefore, this method is one of the leading and even mandatory among teaching methods in informal education in the United States of America. Its application is explained by the fact that adults learning content meets their needs and interests, and thus is directly linked to existing life experience and the need to address certain issues. However, according to A. Fingeret (2017), the method allows to touch inner world of man, his perception of the world, thoughts and beliefs. 
It is necessary to pay attention to the fact that narrative method presupposes not only interpretation of previous experience of an adult, but his inclusion in a new experience, because American scientists consider constructing narrative as an effective means of achieving goals of training (Levine, 2016; Merrifield, 2018).

Understanding the nature of narrative method made it possible to ensure that it is an important component of case-method, role and business games and others.

Interesting and effective method of learning in informal adult education in the USA is, in our opinion, the method of budding, which can be defined as assistance partnership. Sometimes it is called informal mentoring or peer coaching. For example, in Cambridge Adult Education Center the following recommendations were developed for the usage of budding in the learning process: be sure to create an atmosphere of trust; understand the needs and expectations of adult learners; define goals that should be achieved; do not impose your views, respect the others; establish interactive communication. It should be noted that budding is most often used in training in the workplace (Askov, 2016).

Simulation is efficient and effective in informal adult education method and it is associated with playing a real life situation. It belongs to gaming techniques that are widely used in informal adult education in the USA. However, the method of simulation is different from other gaming methods, for it is aimed to develop skills of judgment, consequences of one's own actions, and its feature is immediate reaction of a student to simulated situation and possibility of replacing external factors of motivation for learning motivation situation, motivation experience. According to E. Askov (2016), simulation method is valuable not only for the inclusion of a specific type of activity, and the result that person receives at the end of the game.

American scientists emphasize the importance of using of dialogical learning methods, including the method of dialogue, discussion, "brainstorming" and others in informal adult education. Dialogical methods are called methods of "finding consensus", since an exchange of views between the participients, leads to the synthesis of experience, better understanding of the problem and finding of optimal solution. Their essential characteristics are: engagement, trust and respect between the subjects of study, equality, understanding (Levine, 2016; Merrifield, 2018).

The method of debate is the most effective teaching method that is widely used in American educational practice. Discussion sections are organized to discuss different issues. It is advisable to organize a debate on the principle of transformation to address the problem through a combination of theory and practice. It is especially important for adult students to discuss personal values, topics and results.

One of the widely spread method is fishbone diagrams, which is the literal translation of the name - "Diagram fish skeleton". This method focuses not only on the problem, but also on related issues to it. That is the main problem - a fish head, bones of skeleton and approaches to its solution with in-depth analysis of such problems, and a tail the decision (Comings, 2016). Fishbone method refers to methods of problem-based learning, allowing involve human experience thorough analysis and the ability to make connections between facts.

Thus, interactive learning technologies are used in informal adult education on the basis of the following principles: collaboration, voluntary, activity, democracy, mutual support, mutual benefit for the allowing adult students to fulfill their personal and professional potential.

Research shows that distance learning technology that is based on modern information and communication technologies creates entirely new opportunities for innovative changes and is widely used in adult education in the USA. 
It is notable that the United States of America have an old tradition and experience in distance education. Nearly every American state has a program of distance learning. Results of the study conducted by the National Center of Statistics revealed significant distribution and acceptance of distance learning. So, in 2012, distance education increased by $30 \%$ and turnover to e-learning tools increased in 2.3 times (Lasater, 2014).

According to the survey conducted in the USA in 2009, technology is recognized as effective distance learning means and one that requires active implementation and dissemination of adults learning (Demetrion, 2005). Today, distance learning programs are used by more than one million students in the USA. Since 1990, these programs were included into adult education and actively supported by 1.500 educational institutions, nongovernmental organizations, associations and other providers that offer a variety of courses that can satisfy the most demanding needs of adult education.

In 2011, the idea of MOOES - massive open online courses, which is an international project, was implemented. MOOES differ from conventional distance learning courses, each course - a combination of video lectures, texts, learning objectives, educational forum. Materials are available at any time, in any place, one only needs to have access to the Internet. Evaluation of knowledge takes place in test centers that are around the world or online through a special program.

\section{CONCLUSIONS}

Conducted research gave the possibility to state that educational technology is systematic targeted approach to learning that combines specific teaching methods and takes into account psychological part of the learning process - relationship between learners and those who teach; systemic ways of activities of those who teach and those who study for the effective achievement of learning goals. Principles of educational technology usage are: individualization, creativity, self-motivation, cooperation, activity. Interactive learning technology is based on the interaction between participiants of training; organization of joint activities based on dialogic teaching methods; a way of organizing learning of adults considering the needs, interests, personal and professional experience. Basic forms and methods of adult's interactive teaching in the USA are: conversation, discussion, collective solving of creative situations, the method of "round table", project method, playing techniques, mentorship, coaching - training in small groups, storytelling, narrative method.

Our future research work will be aimed at analysis of structural peculiarities of adult education in the English-speaking countries.

\section{REFERENCES}

1. Amstutz, D. (2011). Adult basic education: equipped for the future or for failure? In P. A. Sissel (Ed.), Making Space: Merging Theory and Practice in Adult Education (pp. 182-194). Westport, CT: Bergin and Garvey Publishers.

2. Askov, E. N. (2016). Adult literacy. In A. L. Wilson \& E. R. Hayes (Eds.), Handbook of Adult and Continuing Education (pp. 247-262). San Francisco, CA: Jossey Bass.

3. Barton, P. E., \& Jenkins, L. (2015). Literacy and dependency: the literacy skills of welfare recipients in the United States. Princeton, NJ: ETS Policy Information Center.

4. Comings, J. P., Reder, S. M., \& Sum, A. (2016). Building a level playing field the need to expand and improve the national and state adult education and literacy systems. San Francisco, CA: Jossey Bass. 
Sciendo Порівняльна професійна педагогіка 9(3)/2019

Comparative Professional Pedagogy 9(3)/2019

5. Demetrion, G. (2005). Conflicting paradigms in adult literacy education: in quest of a U. S. democratic politics of literacy. Mahwah, NJ: Lawrence Erlbaum Associates.

6. Fingeret, A., \& Drennon, C. (2017). Literacy for life: new learners, new practices. New York, NY: Teachers College Press.

7. Knowles, M. (1984). Informal adult education. New York, NY: Association press.

8. Lasater, B., \& Elliott, B. (2014). Profiles of the adult education Target population: information from the 2000 Census. Research Park Triangle, NC: Center for Research in Education.

9. Levine, K. (2016). The social context of literacy. London: Routledge \& Kegan Paul. 10. Merrifield, J. (2018). Contested ground: performance accountability in adult basic education. Cambridge, MA: National Center for the Study of Adult Education.

11. Quigley, B. A. (2017). Rethinking literacy education: the critical need for practice based change. San Francisco, CA: Jossey-Bass Publishers. 